\title{
Towards a sustainable city through system innovation implementation: Case study of reinventing Kebon Sirih Jakarta as an inclusive tourism spot
}

\author{
Tusy Augustine Adibroto ${ }^{1 *}$, Tiktik Dewi Sartika ${ }^{2}$, Annisa Wardhani $^{3}$, and Rudi Nugroho ${ }^{1}$ \\ ${ }^{1}$ Environmental Technology Centre, Badan Pengkajian dan Penerapan Teknologi, Tangerang \\ Selatan, 15314, Indonesia. \\ ${ }^{2}$ Tourism and Creative Industry, Universitas Muhammadiyah, Tangerang, 15118, Indonesia. \\ ${ }^{3}$ MICE, Politeknik Negeri Jakarta, Jakarta, 16424, Indonesia.
}

\begin{abstract}
A tourism spot at the heart of the Jakarta-capital city of Indonesia is facing a crisis due to the fast-growing city development. Action research to revitalize Kebon Sirih tourism is implemented. Using Asset Based Community Development approach in unveiling the current potentials and with system innovation principles to connect and coordinate stakeholders while initiating the development of three iconic communitybased tourism activities: Cultural Exhibition Centre, Culinary Centre, and Environmental program in Kebon Sirih. This initiative is realized through the collaboration of academes (DRD, BPPT, IPB, DKJ), LGU's, community organizations (Rujak Center, Sanggar AKAR, and Saung Angklung Udjo), and the local community.
\end{abstract}

\section{Introduction}

According to SDG Report in 2018, the world's population lives in cities or urban centers more than $50 \%$ of the world's total population. Even further estimated by 2030, cities will be home to $60 \%$ of the global population, while by 2050 , it is estimated to increase up to about $68.4 \%$ [1]. In the last twenty years, the global community has witnessed the emergence of urbanization as a key development trend (both in the context of the MDGs and SDGs).

The 2030 Agenda for sustainable development, through the endorsement of a goal in cities (Goal11), known as the 'urban SDG.' Urban SDG should make cities and human settlements inclusive, safe, resilient, and sustainable. The world's cities can drive innovation, consumption, and investment around the world. Cities can deliver positive and strong force to tackle sustainable economic growth, urban development issues, and prosperity. The current fact is that cities have become the biggest contributors to economic growth. Cities already contribute about 80 percent of global GDP and serve as catalysts for innovation and inclusions.

\footnotetext{
* Corresponding author: tusyadibroto@gmail.com
} 
Indonesia, the 4th most populous country globally, has a fairly high urban population. In 2019, Indonesia's urban population was 151,509,724, 2.31\% increase from 2018 [2]. The dominance of the urban population over the population in Indonesia increases every year. In 2019 the urban population in Indonesia $55.8 \%$ of Indonesia's total population of 270.6 million. As Indonesia's capital city, Jakarta is one of the most populous cities in the country, with an estimated 10,770,487 people flocking in (population.un.org). As a global city, Jakarta also has severe environmental problems such as poverty, transportation, energy, water, and sanitation [3].

This research elucidates an endeavor put in one of the Jakarta - Indonesia's capital city hotspots, Kebon Sirih, an area in the Central Jakarta used to be well known as "backpackers tourism destination". That area whose condition now pushed with the vast city growth, high rise buildings, and land-use change that push the communities to their edge of confusion and hopelessness. With the approach of innovation system theory and community participation principles, community-based tourism links all the remaining elements in the area. A hope is rebuilt for a better and sustainable community for a sustainable city tourism spot.

This research's initial goal is part of the roadmap of system innovation fortification in the Jakarta Research Council (DRD DKI Jakarta). That is also in line with the governor's mission to promote Camat or Lurah (head of district/sub-district) as urban managers who drive innovation in his area. While academically, this research aims to contribute to the science and knowledge, expected to provide input for policymakers and local government officials, as well as promote community empowerment and capacity building. At the same time, it is finding out a pattern or model that fits for revitalizing Kebon Sirih as a multicultural and inclusive tourism icon in Jakarta.

\section{Method}

This study uses a tool called $A B C D$ (Asset-Based Community Development) to map the local community's potentials and physical conditions at the study site. Research is conducted through observation, survey and interview, desk study, questionnaire, roadshow, and community mapping. In contrast, the in-depth interview with community elements is conducted with eight respondents consisted of 1 Head of Sub-district, 7 Head of RW's (Neighborhood Groups).

To have more detailed information, roadshows are done to several related Local Government Unit (SKPDs):
a) Central Jakarta Mayor's Office (Kantor Walikota Jakarta Pusat)
b) DKI Jakarta Tourism and Culture Office (Dinas Pariwisata dan Budaya DKI Jakarta)
c) Parks and Cemeteries Department (Dinas Pertamanan dan Pemakaman DKI Jakarta)
d) Community Empowerment and Family Planning Coaching Agency (Badan Pemberdayaan Masyarakat dan Pembinaan Keluarga Berencana /BPMPKB)
e) DKI Jakarta Provincial Development Assistant (Asisten Pembangunan DKI Jakarta)
f) Taman Ismail Marzuki Technical Implementation Unit (UPT Taman Ismail Marzuki)
g) Discussions with NGOs and the community: 1) Rujak Center (Jakarta Study Center - Jakarta Room / Rujak); 2) Sanggar AKAR (Anak Karya) Jakarta, and 3) Saung Angklung Udjo Bandung as one of the management references cultural folk performance activities.




\section{Results and discussion}

\subsection{Literature Review}

\subsubsection{Innovation}

Innovation has been shifting from the economic and academic domain (as an evolutionary mechanism in a company driven by science and technology findings) to the area of social development known as social innovation (as a tool to reach social and development goals) [4]. The need for innovation is equal with the need to change, except the nature of innovation is comprehensive, and therefore it is also known as system innovation. System innovation is needed when the available tools can no longer solve existing problems [5].

From several theories explored, we could point out that innovation's core principles lie in the interaction and learning process [4]. Stakeholders in Kebon Sirih and Central Jakarta are expected to interact, share ideas and solutions, act together, bring forth system innovation, which is from all (stakeholders), by all (stakeholders), and for all (stakeholders). The major, minor societal elements, businesses all inclusively and participatory work hand in hand, share information, absorb lessons, and build something new, fresh, and socially impactful program.

Based on the driver stakeholders, Bruijn [5] found at least three types of system innovation: a) knowledge-driven, b) government-driven, and c) market-driven. While Miedema [6] mentioned, Pro-poor innovation referring to innovations for those communities whose income below $\$ 2$ per day or known as the Base of the Pyramid (BoP). This research is of mixed type $\boldsymbol{a}$ and $\boldsymbol{c}$.

Studies of research councils in Asia and worldwide suggest all social levels' involvement to innovate as an alternative way of alleviating poverty. The inclusive innovation approach is widely used by development organizations such as UNDP, OECD, and IDRC to achieve development goals, including alleviating poverty, reducing inequality, distributing good health and well-being.

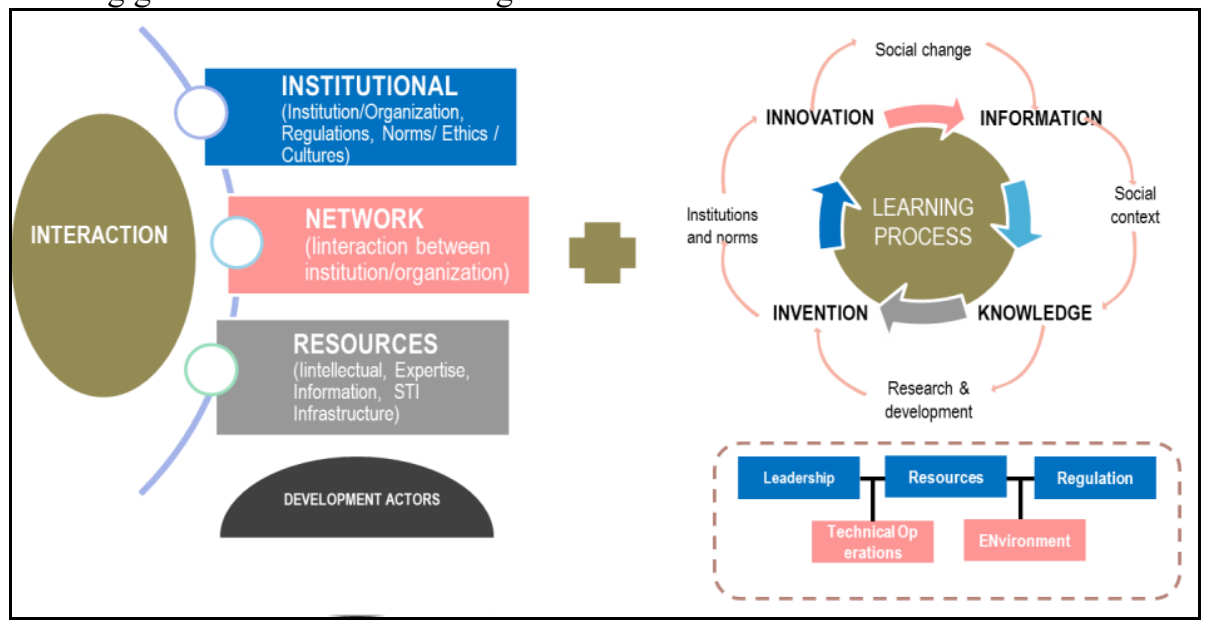

Fig. 1. Principles in Innovation [7].

Given the fact of Kebon Sirih problems, it is important to cite Social Innovation as the type of innovation relevant to refer to. Social Innovation gravitates to innovative activities, products, or process which can contribute to development measures, using collective policies, for together good [4]. It implies both bottom-up (from communities) and top-down 
(authorities) approach. The challenge of this approach lies in the coordination of the network.

The key idea of inclusive innovation is basically in the active participation of all elements, inclusively, in the process of innovation [7], as illustrated in Figure 1. This shall be achieved through community participation and empowerment.

\subsubsection{Asset-Based Community Development}

The asset-based community development (ABCD) framework first developed as an alternative to needs-based approaches in which agencies, universities, or other donor groups 'intervene' on behalf of a community to rectify problems. The needs-based analysis and intervention can be devastating to a community or, at the very least, undermine or compromise existing community capacity-building efforts. On the other hand, ABCD builds on the gifts (skills, experiences, knowledge, and passions) of local community members, local associations' power, and local institutions' supportive functions to build more sustainable communities for the future [8].

The approach of ABCD is to enhance and support the capacity of a community to make visible their assets, as well as support and enhance the connection of those assets. According to McKnight [8], these two essential roles are the way to undergird productive citizenship. ABCD emerged as a critique of deficit-based approaches. The deficit approach focuses on the problems, needs, and deficiencies in a community. It designs services to fill the gaps and fix the problems. As a result, a community can feel disempowered and dependent; people can become passive recipients of expensive services rather than active agents in their own and their families' lives. Below in Figure 2 is a quick look at the difference between needs-based and asset-based approaches.

The ABCD framework is characterized by a method that involves working with members of the community to identify their strengths or assets (mapping) and to articulate a future direction and desired outcomes (visioning), and working with community partners to mobilize strengths in order to help achieve goals (mobilizing) [9].

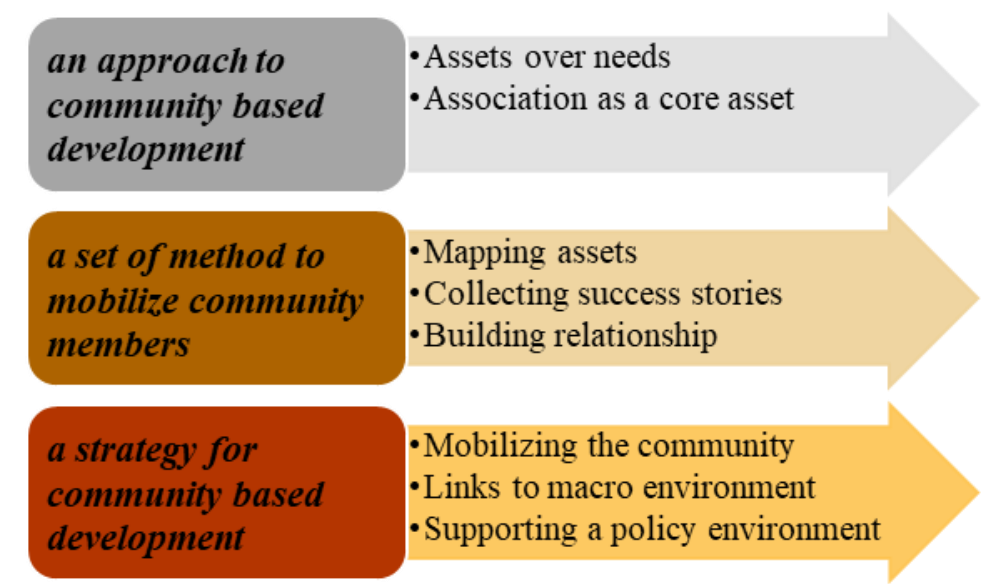

Fig. 2. Conceptualization of the ABCD approach [10].

\subsubsection{Community Based Tourism (CBT)}

In the light of social and inclusiveness in implementing innovation in tourism, the most suitable approach is Community-Based Tourism or CBT. As stated in ASEAN Guidelines 
on CBT, CBT emphasizes the community's self-reliance in operating their tourism activity. At the same time, keep protecting cultural and traditional values and that they possess. In this way, the activities should be more sustainable as their livelihood, while natural and cultural resources will remain preserved [11].

In the context of Kebon Sirih, revitalization of the area as a tourism destination will include activities that will support sustainable livelihood while maintaining Betawi as well as Indonesian cultural heritage. Such endeavors would involve a lot of commitment and consistency from all involved stakeholders and, most of all, the local community.

\subsubsection{Community Participation}

When an innovation emerges out of a system, how can we know that the innovation will sustain? There is no tool to measure innovation sustainability since it is a complex and comprehensive process. Value creation appears at an individual. Instead, they appear at every level of the system, therefore engagement as much as possible actors and parties must favor a more sustainable innovation. Theoretically speaking, community participation and community empowerment are important to producing a sustainable, inclusive innovation [12].

Community participation means the involvement of communities in decisions about their future. In the context of tourism, planning is defined as the process of involving all stakeholders (local government officials, local citizens, architects, developers, business people, and planners) in such a way that decision-making is shared [13]. This is definitely not a new idea. However, the concept survives from the 1950s continues to evolve through time until today.

\subsubsection{Empowerment}

The empowerment concept is viewed as a means and goal to fulfill a basic human need, education, skills, and power to achieve a certain quality of life, which is developed in the 1980s [13]. As well as in participation, Rocha in Okazaki [13] expands the ladder of empowerment but with different categorizations. So, empowerment includes participation in decision-making and the process that enables the community to perceive themselves as able and entitled to make decisions. To realize the community's participation and empowerment, it is important to build awareness of understanding the situation and problems that the community has to face and be ready to go through learning during the process.

In Kebon Sirih case, before this concept was executed, the first step to be taken was raising the community's awareness. Awareness is built in the initial process so that the community is aware of the problems they face as well as potential ways out. This is realized through a motivation building session followed by a focus group discussion series involving all stakeholders called "Rembuk SIDa" [14]. Rembuk is an Indonesian word that refers to not limited to, but including discussion, negotiation, giving, and receiving advice. While SIDa is a short form Sistem Inovasi Daerah, a term refers to regional system innovation applied in Kebon Sirih.

All the above concepts, from community participation, empowerment, and awareness, are all adopted and started by conducting surveys using ABCD as the tool and revealing the three biggest potentials in Kebon Sirih: culture, culinary, and environment. Further, the survey result becomes an input to develop community-based tourism (CBT), which is expected to increase community participation and improve the local community capacity. 


\subsection{Results}

An initial survey was conducted to find out the current condition from objective observation as well as the perception of Kebon Sirih citizens. Kebon Sirih focused area is an area of 47,4 acres (out of 83,4 acres) and inhabited by 5,246 households or 15,631 people (Monthly Village Report, January 2017) each kilometer square inhabited by 18,742 people. Nearly $49 \%$ of the citizens aged $15-44$ years old and $67,4 \%$ of the citizens' livelihoods are as a laborer (unskilled), 30\% are entrepreneurs, and the rest are civil servants, Military/Police Officers, and Retirements. The lands owned by the citizens are $38 \%$, while the land owned by the state reached $26 \%$. The land-use for housing in the area is $73 \%$, and the rest are for a public facility with no allocation for the industry. However, in this area, we can find big hotels, offices, and malls.

There are several important historical buildings in the area, such as Gedung Juang '45, National Monument (Monas), National Museum, and Textile Museum. While for cultural attraction, the area is known for night time and culinary tourism. Interestingly, street culinary in Kebon Sirih is the most surviving activity due to the high demand from the offices and hotel visitors during the day and night. However, since 2014 the governor prohibited street booths and parking along Jalan Jaksa (the main cultural street in the area). This led to the reduction of visitors to the area.

In 2001 City Planning document stated that Jalan Jaksa is designed as a multi-strata tourism region. However, in RDTR DKI Jakarta year 2014, the land is allocated for offices/trading/service as well as settlements. This implied the 2001 planning has already been outdated and forgotten. In fact, in the research area, we found a great number of vacant lands scattered, known to have been claimed and bought by private companies.

Street sellers (PKL) registered in the area should pay retribution per day to the government. Registered PKL's in the Kebon Sirih survey area is 134, while unregistered PKL's are about 43 sellers. There is a tricky situation where the village servants often remind the unregistered sellers not to disobey the local government's rules. However, the sellers keep ignoring this reminder.

In terms of arts and cultures, Kebon Sirih is a culturally important spot in Indonesia's capital city. This area is well known since the 1960s as the symbol of multiculturalism. During the fast-growing development in the 1990s, the 400-meter street was flocked with hostels, cafes, and a yearly cultural festival known as Jalan Jaksa Festival. The festival exhibited arts and cultures of Betawi, a tribe of Jakarta origin, as well as a bazaar. This event had been the main entertainment for local and international tourists as well as a source of income for the surrounding citizens. For decades the festival had been funded by Local Government Funds. However, in the 2015-2017 government stopped these funds so that the festival is no longer held. However, due to the high demand from grassroots, Kebon Sirih local community looked for support and held the festival without any government fund at the end of 2017.

The people's aspiration is that if ever the government supports this festival, the people expect bigger rooms for people to organize since it is said that with government funds followed by rules that are very much limiting the blending of tourists and local cultural activities.

As the support is smaller, the art groups in the community also started to fade away. From the research survey, there used to be art workshops and art groups. However, there are only left Qasidah group activities surviving (the female religious vocal group with rebana percussion). The art groups consist of traditional dancers from children and adults. They no longer practice because they have to study and work to compete in the job market.

The citizens in Kebon Sirih are only had several reasons to stay in the area, i.e., they had been there for generations, near workplaces. Some of them stay because the negotiation with the investor is not finished yet. About 35\% of citizens choose to sell their land and 
houses because of the high-rocketing price and the incomparable social and cultural benefits if they remain staying.

\subsubsection{Citizen's expectation}

Since offices, hotels, and malls dominate the buildings in Kebon Sirih, so it has become magnets for work seekers in Jakarta and outside Jakarta. The Kebon Sirih citizens have difficulty applying to the vacancies available due to the lower qualification in terms of education, experience, and skill. This led to the high rate of unemployment in the productive age of the citizens in Kebon Sirih.

Sanitation is also another issue that the citizen has to face every day. Lack of dust bins and sanitary agency from the government, as well as low awareness from the local citizens, create persistent sanitation problems in the area, such as the clogged drainage with rubbish, the bad smell, and filthy environment.

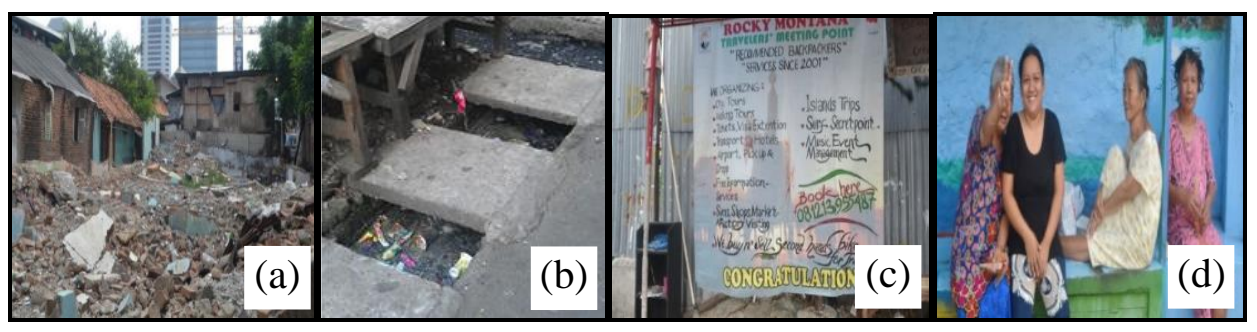

Fig. 3. (a) Claimed Company Land (b) Clogged Drainage (c) Local Tour Booth (d) Community.

In resume, cleanliness, health, clean water, and job opportunities are the main challenges in Kebon Sirih to be resolved for redeveloping the area back into shape (see Figure 3).

Despite the challenges, the citizens still have hope to be able to develop themselves. They hope to get capital to start micro business and capacity building to acquire a new skill or improve their skills. Available vacancies surrounding the area are commonly unskilled and low-paid, which does not interest the productive aged citizens. The shy and laid-back attitude of the youngsters in the area is also another homework to resolve.

\subsubsection{Potentials to revitalize}

Basing on $\mathrm{ABCD}$ principles, questionnaires are analyzed and showed that the citizens in Kebon Sirih have the potentials of cooking iconic cakes or food, selling music instruments, singing, sport, and event organizing.

The dominating skill that the community has is cooking, mostly by the housewives. The tradition of holding the festivals had strengthened this. Some foods or cakes they can cook are of the iconic Indonesia traditional cuisines such as Bubur Betawi, Soto Betawi, Pempek, and other cuisines.

From cultural aspects, the survey showed that there still live traditional artists in the area. However, they do not do cultural activities anymore these days. They said it is more difficult to coordinate. Moreover, the children of the past art workshop have to go to school, so they can no longer be involved in art activities.

Looking through the available potentials that the citizens have, an activity could merge all these skills as well as exhibit their cultural aspects. To revitalize the area, a center of 
attraction needs to be built to showcase these potentials. That resume, culinary is a strong potential as well as culture.

The people's acquisition of information and technology where they are familiar with smartphones and its features is another useful information because they can use the internet to promote Kebon Sirih. Also, Jakarta has a Smart City program that enables the Jakarta citizens to interact and communicate their complaints and needs to and from the government. In this way, citizens will be involved in the development process.

More hope appeared as a public place is established in 2017 named as Child-Friendly Green Open Space (RPTRA) Kebon Sirih, the place that was initially chosen by the research team as one of the survey results. This indicated that the initial study result was reported to the local government directly applied by the local government. This park is developed by the collaboration of government and private companies, providing space for children, mothers, and the elderly to create activities in the area.

\subsubsection{Challenges}

Developments bring changes to the community and the environment. Sometimes one development is not followed by other adjustments, then unexpected problems emerged. The high mobility, massive vehicle flows, consumption, job market competition, creates traffic, bad road, pollution, low sanitation, and a bad environment. Based on observation and survey conducted, the main problems in Kebon Sirih are including:

Table 1. Problems in Kebon Sirih.

\begin{tabular}{|c|c|c|}
\hline No. & Aspects & Problems \\
\hline 1. & $\begin{array}{l}\text { Spatial planning and Public } \\
\text { Facilities }\end{array}$ & $\begin{array}{l}\text { - The street is too narrow } \\
\text { - inappropriate land-use, settlement for commercial } \\
\text { - The very little space for parking and public toilet } \\
\text { - No Public space available for community interaction } \\
\text { - Narrow pavement }\end{array}$ \\
\hline 2. & $\begin{array}{l}\text { Street flow, health, and } \\
\text { environment }\end{array}$ & $\begin{array}{l}\text { - } \text { street circulation/traffic flow } \\
\text { - Pollution } \\
\text { - hygiene and sanitation } \\
\text { - the depletion of visual and environmental quality } \\
\text { - lack of support from big commercial actors }\end{array}$ \\
\hline 3. & Community & $\begin{array}{l}\text { - Average income is very low } \\
\text { - Unskilled labor is dominating } \\
\text { - They have potentials but difficult to develop } \\
\text { - The indigenous community is fewer (pushed aside by } \\
\text { land use-change) }\end{array}$ \\
\hline 4. & $\begin{array}{l}\text { Regulation/Support, } \\
\text { Government/Institutional }\end{array}$ & $\begin{array}{l}\text { - Prohibition of street-food stall results in the loss of } \\
\text { income in the community } \\
\text { - The lack of government support for art/culture } \\
\text { activities in the area } \\
\text { - The region has yet become a special tourism region } \\
\text { and is not prioritized in the development agenda } \\
\text { - The government's policy prohibits guesthouse in the } \\
\text { area }\end{array}$ \\
\hline 5. & Tourism & $\begin{array}{l}\text { - } \quad \text { The number of tourists has drastically depleted. } \\
\text { - } \quad \text { Many guest house/ homestay/ lodgings are closing } \\
\text { - On the contrary, budget hotels are springing } \\
\text { - Jalan Jaksa Festival (as a trademark) held } \\
\text { irregularly } \\
\text { - no culinary activity in Jalan Jaksa corridor }\end{array}$ \\
\hline
\end{tabular}




\subsubsection{Rembuk SIDa}

The research in Kebon Sirih is action research and part of the roadmap of the regional system innovation fortification program from the Jakarta Research Council (DRD DKI Jakarta) to find the right action and policy revitalizing Kebon Sirih as a tourism destination.

From the findings on-site, it is realized that a systemic innovation needs to be built to revitalize the area, which is based on the interaction of various stakeholders and strengthening community participation and capacity. Aspiration from the community and DRD DKI Jakarta narrowed down to establishing three programs: a) capacity building, b) develop cultural icon and revitalizing culinary centers, and c) revitalizing the environment.

To reach the above goals, all the targeted stakeholders gathered and drew commitment through the "Indonesian way", an activity called "Rembuk" or in Bahasa Indonesia Dictionary rembuk $/ \mathrm{rem} \cdot \mathrm{buk} / \mathrm{n}$ bicara; nasihat; means speak up; giving advice. Through this, it is expected that participants will actively speak up about their problems and needs while others are giving constructive suggestions and necessary policies needed to support the ideas. This is in line with regional system innovation (SIDa) that emphasizes learning and interaction, as well as establishes an interconnected relationship, the institutionalization of interaction. Thus, the endeavor is called Rembuk SIDa.

The implementation approach used in Rembuk SIDa is through community empowerment steps [14]: a) awareness building, b) capacity building, c) empowering, and participating. For the execution of Rembuk SIDa, Jakarta Research Council (DRD DKI Jakarta) is fully supported by the Local Government in coordination with Kelurahan (subdistrict government) Kebon Sirih. Who actively invited the community leaders that reached about 58 participants, mostly consists of the local community and LGU's certain divisions. For awareness and motivation building, a cultural influencer, an Indonesian artist concerned with community and children education, Dik Doank, is involved. The forum also invited facilitators from academes known as an inclusive culinary expert Prof. Aida Vitayala from IPB (Bogor Agricultural Institute), a culture expert Dr. Irawan Karseno, Director of Jakarta Art Council (DKJ), and expert of environment Dr. Sri Wahyono from the Agency for the Assessment and Application of Technology (BPPT).

This Rembuk aimed at obtaining inputs and confirmation of a) problems, b) potentials, and c) community needs. As part of capacity building, the forum is grouped into three groups based on three activities going to be implemented (culture, culinary, and environment).

The first group is the cultural capacity building. That group is followed by the community, sub-district officials, association of Jalan Jaksa and around touristic entrepreneurship (IKJS), and Children Art Workshop officials. From the discussion, Irawan Karseno mentioned an ongoing concept of developing Jakarta as Arts and Cultures City in several iconic spots in Jakarta, such as Kota Tua, Taman Ismail Marzuki/TIM, et cetera. It is expected that the Grassroot Cultural Exhibition in Kebon Sirih can be integrated into the concept. With the available potentials where community members can play an instrument, sing, and organize events, as well as traditional martial arts, it will all be possible to materialize.

The Second Group discusses culinary development suitable for Kebon Sirih. The facilitator for this group is Prof. Aida Vitayala from IPB (Bogor Agricultural Institute). This group is followed by Ibu-ibu PKK (housewives) in the community who are basically just home cook and not a street-booth entrepreneur. The forum shares how to prepare quality food and to survive in competition among other sellers. The forum emphasizes the necessity to have Koperasi Makanan Jajanan, a cooperation unit specified for street food.

The Third Group is facilitated by Dr. Sri Wahyono (principal researcher of BPPT). The discussion is focused on the garbage management and greening program in the Kebon Sirih area. It is suggested to apply Bank Sampah (Garbage Bank) and the use of composter or 
biodigester as fertilizer for greeneries to be applied. The biodigester can also be the gas supplier substituting LPG. While greeneries can be implemented using beautification in limited space, using hydroponic and verticulture techniques, and choosing edible plants and medicinal herbs to grow. The discussion also emphasizes the importance of water conservation to avoid the flood. It is double aims, aesthetics, and ecological.

\subsection{Discussion}

This action research is expected to apply principles in innovation and create a learning experience for the stakeholders involved, especially Academician, Business sector, government, and ultimately the community.

\subsubsection{Learning process in local government}

District/Sub-District servants are the key actor to be the urban manager of this revitalization program (see Figure 4). The leader in the district/sub-district office is called Camat/Lurah. A Camat/Lurah is expected to function not only for government administrative but also to play the role of manager for a technical issue such as public health, security, community empowerment, as well as environmental maintenance.

Therefore, to be able to coordinate and manage all the above things, an urban manager should have multi-disciplinary knowledge, starting from urban planning, economy, social politics, asset management, and city infrastructure. He should be able to maintain good communication with the community, friendly, and service-oriented. The community is very motivated to start the program yet still lacks financial capital, and therefore he has to be more active to look for financial support.

\subsubsection{Learning process in the local community and Rembuk participants}

First, the key to capacity building is Learning. Learning occurs at the individual, organizational, community level. Rembuk SIDa acts as the initial step of learning. Continuing all related stakeholders to keep sharing information and supports will be the key for all parties to become capable of carrying out their roles in the group.

Second, from Rembuk, all parties understand their position in the program. The revitalization program will depend on human resources support who are capable of managing physical and non-physical potentials available to improve prosperity.

The third and most important lesson from this study is that it is important for all actors and stakeholders, such as the community, academicians, government, non-government, and the commercial private sector, to co-learn and develop the network. Simultaneously, the network further institutionalizes the network into an organization or a forum, for example, a Cultural Innovation Forum. This way, each step of implementation and milestone achieved will be well-monitored and measured to achieve the goals. 


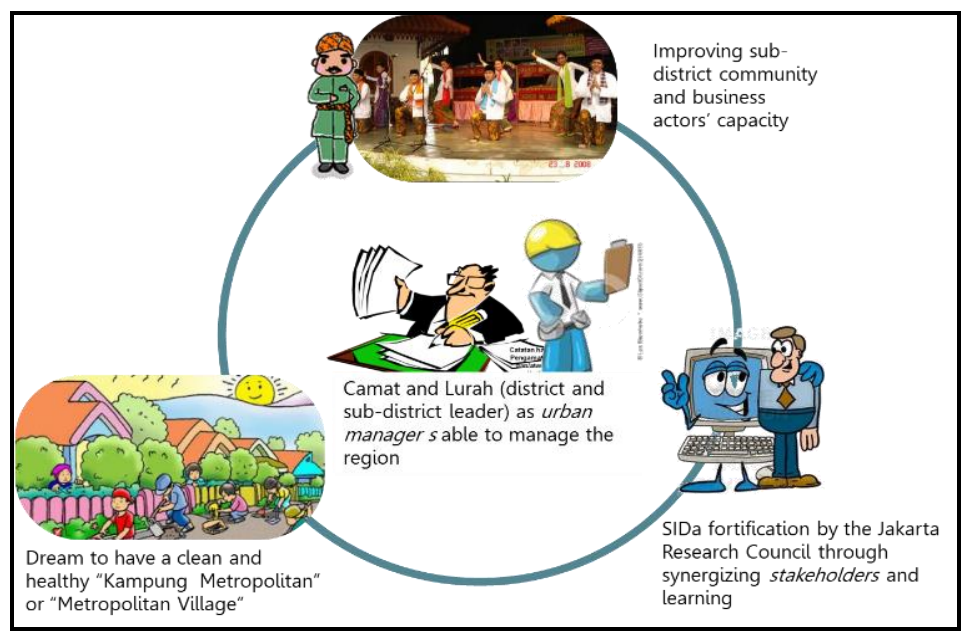

Fig. 4. Urban Managers and Metropolitan Village Idea [7].

Lastly, the role of Jakarta Research Council (DRD DKI Jakarta) as the intermediator for running an innovation. In the world of innovation, the role of an intermediator is one of the keys. Although the system had complete actors' components, those dots will not be connected without an intermediator. So, the role of an intermediator is "connecting the dots".

Several key inputs of this research had been referred to and included in the yearly development program by the government of Central Jakarta City, i.e., the development of 6 region-based locations, including Kebon Sirih. Kebon Sirih development area called BANGJAIM (short from Jalan saBANG, Jalan JAksa, and around Jalan wahid hasyIM) with the recommended approach by the research team. The program has become the yearly agenda of Musrenbang Provinsi DKI Jakarta (the Development Planning Forum of DKI Jakarta province) from 2018 to 2020.

\section{Conclusion}

An innovation initiative should be tailored to the existing local condition and must in all power to gather all resources and potentials to work together. Participation of all stakeholders, the role of urban managers, and the intermediator's role are keys to the success and sustainability of revitalization of Kebon Sirih as an inclusive tourism spot in Jakarta, Capital City of Indonesia.

From this research, we found out despite the problems that Kebon Sirih is facing (see table 1), there are three community' potentials recommended to be developed as local development icons: 1) Cultural Exhibition Center, 2) Culinary Center, and 3) Environmental program. This can be materialized through collaborating all of the stakeholders, in this case, including the experts from the academe (BPPT, IPB, DKJ, and DRD), related LGU's and community organizations (Rujak Center, Sanggar AKAR, and Saung Angklung Udjo) as well as local communities. Further, supporting policy is critical, such as government policy that is in line with several recommendations from this research. Among others is the provision of land for exhibition and cultural center that is responded by the local government with the establishment of the children-friendly green open space (RPTRA) in Kebon Sirih.

This implementation of system innovation through community empowerment for more sustainable development is gaining positive response from local government (Central 
Jakarta Government) that the idea had been adopted to develop six chosen region in central Jakarta. The development of 6 regions is mentioned in the yearly development planning (Musrenbang) of the Central Jakarta from 2018 to 2020.

\section{References}

1. United Nations, SDG 11 Synthesis Report, (2019)

2. World Bank, Urban Population Growth - Annual (\%)- Indonesia, (2018)

3. D. Edelman, Curr. Urban Stud. 8, 57 (2020)

4. T. A. Adibroto, et. al., Reinventing Metropolitan Village. Concept Implementation of Regional System Innovation Approach in Revitalizing Kebon Sirih Inclusive Tourism Region. (The Jakarta Research Council, BPPT Press, Jakarta, 2018)

5. H. De Brujin, H. Van der Voort, W. Dicke, M. De Jong, and W. Veeneman, Creating System Innovation, How large scale transitions emerge, (Leiden, A.A. Balkema Publishers, 2004)

6. M. Miedema, N. Chevrollier, et. al., TNO Innovation for Development. Socioeconomic impact at the poor in developing countries, (The Netherlands, 2010)

7. T. A. Adibroto, et. al., Presentation Materials in Stakeholders Meeting in Rembuk SIDa, (Jakarta Research Council, Jakarta, 2016)

8. J. McKnight, Asset-Based Community Development: The Essentials, (ABCD Institute, 2017)

9. Fisher, Kyla, et, al., Bus. Ethics Eur. Rev. 18, (2009)

10. A. Mathie and G. Cunningham, Dev. Pract. 13, 474 (2003)

11. ASEAN, ASEAN Community Based Tourism Standard, (Jakarta, 2016)

12. Oeij, Peter R.A, et. al., J. Bus. Res. 10, 243 (2019)

13. E. Okazaki, J. Sustain. Tour 16, (2008)

14. T. A. Adibroto, et. al., Rembuk SIDa, Pioneering Revitalization of Kebon Sirih Tourism Region, (The Jakarta Research Council, BPPT Press, Jakarta, 2017) 